\title{
Behavioural and Socio-economic Implications of HIV/AIDS Patients on Population and Development of Ebonyi State, Nigeria: 2010-2014
}

\author{
Anthony Chukwuma Nwali ${ }^{1}$, Rev. Sister Clementina Kalu ${ }^{2}$, Chimeziem Chimdiadi Udeze ${ }^{1}$, Iroegbu Ngozi \\ Franca $^{1}$, Chinazor Franca Obi ${ }^{1} \&$ Nicholas Ihentuge Achilike ${ }^{1}$ \\ ${ }^{1}$ Department of Business Administration, Alex Ekwueme Federal University Ndufu Alike, Ikwo, Ebonyi State, \\ Nigeria \\ ${ }^{2}$ Department of Accountancy/Banking and Finance, Alex Ekwueme Federal University Ndufu Alike, Ikwo, \\ Ebonyi State, Nigeria ${ }^{1}$ \\ Correspondence: Anthony Chukwuma Nwali, Department of Business Administration, Alex Ekwueme Federal \\ University Ndufu Alike, Ikwo, Ebonyi State, Nigeria. E-mail: nwalianthony8@gmail.com
}

Received: February 1, 2020 Accepted: April 18, 2020 Online Published: April 27, 2020

doi:10.5539/gjhs.v12n6p106 URL: https://doi.org/10.5539/gjhs.v12n6p106

\begin{abstract}
Background: Studies indicate that HIV/AIDS has become one of the leading causes of death Worldwide since it was discovered over 30 years ago. The virus has challenged medical solutions and it poses serious socio-economic challenges to most African countries and Ebonyi state in Nigeria in particular. However, the relationship between the behavioural pattern of HIV/AIDS patients, population growth and economic development has not been established in Ebonyi state. Therefore, the study aims to determine the socio-economic impact of HIV/AIDS on population growth and economic development in Ebonyi state, Nigeria.

Method: Survey research approach was adopted and information was generated from primary sources. The information was subjected to rigorous content and validity analysis to establish their consistency and reliability. Federal Teaching Hospital, Abakaliki (FETHA) was selected for the study due to the strategic location of the institution. 210 HIV/AIDS patients were selected randomly and the descriptive method of data analysis was used. Reported HIV/AIDS cases in the hospital between 2010 and 2014 were 2583.

Results: Findings revealed that $61.9 \%$ of those living with the virus are female and the rest male, while $76.2 \%$ have tertiary education, $71.9 \%$ are between 26 to 64 years old, $46.2 \%$ are single, $56.7 \%$ contracted it through sexual intercourse, $94.3 \%$ have been living with it for between $1-8$ years, $71.4 \%$ engage in unprotected sexual intercourse since they contracted it while $85.3 \%$ are desirous of transmitting the virus to others before they die. The spread of the virus is associated with causal/unprotected sexual habits, poverty induced prostitution, indecent dressing, uncontrolled access to social network and improper use of condom.

Conclusion: The study reveals a strong relationship between HIV/AIDS, economic development and population growth and recommends establishment of special task force to check indecent/offensive dressing, attitudinal/behavioural change/modification of the patients and control on the use of social network by the youth as measures to check the further spread of the virus in the state.
\end{abstract}

Keywords: Productivity, population growth, HIV/AIDS, Behaviour, development

\section{Introduction}

The term AIDS means Acquired Immune Deficiency Syndrome, was first noticed in the United States (USA) in 1981 (Sharp, Shaw, \& Hahn, 2005). Subsequent studies were conducted to investigate the causative agent of human immunodeficiency virus type 1 (HIV-1). These studies attributed the disease to retrovirus (Anglemyer, Rutherford, Horvath, Baggaley, Egger and Siegfried 2013). Sharp et al. (2005) argues that as the strains of HIV-1 were globally sampled, it was discovered that they exhibit extremely high genetic heterogeneity and that analysis of the evolution of this diversity gave insights into the pre-history of the virus. HIV-1 strains are categorised into three distinct groups with different prevalence. Groups ' $\mathrm{N}$ ' and ' $\mathrm{O}$ ' are not common and largely restricted to Cameroon and their surrounding countries (Sharp et al., 2005) while HIV-1 group 'M' causes about $98 \%$ of HIV infections world-wide. It may be important to note that within group ' $M$ ', there is very high diversity and the epicentre is in Africa particularly Kinshasa in the Democratic Republic of Congo (Vadal, 2000). Due to the fast 
rate of evolution of HIV-1 group 'M', the virus circulated within human populations for many before it was noticed.

When HIV-1 was first described, the closest known relative was visna, a virus from sheep that is the prototype member of the genus lent virus. Additional lent viruses were soon found in other primates, and a second virus (HIV-2) was found infecting humans. The virus from non-human primates were termed simian immunodeficiency virus (SIVs). Vadal (2000) notes that African green monkeys (chlorocebus specie) were among the first species to be found to be naturally infected. Previous studies showed that SIVs are naturally found infecting primates in Sub-Saharan Africa. Where multiple strains of SIVs have been characterised from a single species, they generally form a monophyletic clad, indicating that the great majority of transmissions are intra specific. The primate viruses as a whole, including HIV -1 and HIV-2, form a distinct clad within the lent viruses, indicating that humans acquired their infections from other primates, (Bailes et al., 2002). Hirsch, Olmsted, Murphy-Corb, Purcell and Johnson, (1989) submit that HIV-2 was first found among individuals from West Africa. In 1989, a closely related SIV was found in a monkey, the sooty mangabey (cercocebusatys), whose natural range is in West Africa.

The virus (AIDS) is affecting development and population growth all over the World most especially in developing countries. It is threatening to both social and economic development therefore the treatment must be accompanied with other social methods to promote physical, mental and social wellbeing (Eaton and Kalichman, 2009) in Kalichman, Demetria and Leickness (2010). Pepin (2011) traced the virus to Central African bush hunters in 1921 where the Colonial mechanical personnel used improperly sterilized syringe and needles and continued to spread the virus silently in Africa for decades. Pepin, (2011) also claims that a Haitian teacher returning from Zaire in the 1960s brought the virus to America pointing out that "sex tourism and contaminated blood transfusion centres eventually pulled AIDS to public consciousness in the 1980s".

Further studies conducted by Merson, O’Malley, Serwadda and Apisuk. (2008) informed that the Centres for Disease Control were the first body to cry out in 1981 about the pandemic known today as AIDS. In 1983, a group of researchers in France isolated a retrovirus later called HIV from an AIDS patient and thereafter, the disease called AIDS was discovered to be caused by HIV. The scourge continued to spread and in 2003 in Swaziland and Botswana, almost four out of ten sick people tested HIV positive, (Carroll, 2003) and in 2011, WHO and UNAIDS advised that a once daily antiretroviral tablet significantly reduced the risk of heterosexual transmission in couples based on the findings of two trials conducted in Kenya, Uganda and Botswana.

Studies conducted by Bonnel (2000) observed that the spread of HIV/AIDS is associated with economic, social-cultural and epidemiological variables and that economic factor centres on labour migration, poverty, economic and gender inequality that expose the society especially the youths to risky behaviours. Detachment from loved ones, occasioned by uneven development among countries/states, exposes the youths to unprotected sex and risky behaviours. Migration disrupted traditional values and favoured sexual promiscuity. Egerton (1938) reports that in the nascent cities, women felt liberated from rural tribal rules and it negatively affected their chances of getting married. Culture is the way of our life, the fundamental rights of the person, value system, traditions and beliefs that define a society (Conjoh, Zhou, \& Xiong, 2011). Some cultures believe that unprotected sex enhances the masculinity of men and therefore any sex practices that discourage flesh to flesh contact are unethical. Ijaiya, Usman, Ijaiya and Alabi (2007) point out that in some parts of Asia, heterosexual contact is one of the ways through which HIV/AIDS spreads.Lamptey, Wigley, Carr and Collrymore (2002) observed that epidemiological study carried out recently revealed that genital/anorectic ulcer disease and non-ulcerative Sexually Transmitted Diseases (STD) are important co-factors in the acquisition and transmission of HIVsex.

UNAIDS (2006) noted that the incidence of infections increased dramatically and the upsurge is traceable to ignorance, poverty and behaviour. Behaviour is a response of an individual to an action, environment, person or stimulus and defines the mental capacity, physical, emotional and social activities experienced during the five stages of human beings' life (pre-natal, infancy, childhood, adolescence and adulthood) (Kinicki \& Kreitner, 2003). Ivan Pavlov (1927) revealed that identifiable Stimulus-Response (S-R) condition reflexes are the basic elements of all behaviour (Luthans, 1985). Human behaviour is dictated by culture, society, values, moral, ethics and genetics. Kiniki and Kreitner (2003) submit further that behaviour involves self-monitoring that depends on own self-expressive behaviour. Luthans (1985) alludes that 'the key to understanding human mind was an understanding of how it functions rather than the pattern of structure'.

"Development is a process of "achieving sustained rates of growth of income per capita to enable a nation expand its output at a rate faster than the growth of its population (Todaro\& Smith, 2011)". Duddley (1996) in Todaro and Smith (2011) observed that economic development is conceptualised in terms of poverty, unemployment and inequality reduction, and that development occurs 'if all three (poverty, unemployment and inequality) have 
declined, but that if one or two of these central problems are growing worse, especially all the three, the result is "underdevelopment" even if per capita income doubled". In contrary, Goulet (1971) in Todaro and Smith (2011) argued that development is multidimensional involving major changes in the society. Heiman and Artiga (2015) in Omotayo, Kantharuben and Wilbert (2020) note that health outcome, level of development and the quality of life of individuals significantly depend on the socio-economic forces.

HIV/AIDS induced mortality rate has demographic implications on population growth. It creates imbalance in age pattern that causes shortage of labour force. Globally, more than 75 million people are added to the world's population yearly and $97 \%$ of this comes from developing countries (Todaro \& Smith, 2011). Population growth goes beyond mere numerical increase but the consequences on the well-being of the people, economic and social implications for development. Population Reference Bureau, (2010) informed that between 1750 to 1950, 1.7 billion people were added to the world population and that in just four decades, 1950 to 1990, population doubled; bringing the figure to 5.3 billion and 6 billion by year 2000 and a projected figure of 9.2 billion by 2050 . People under the age of 15 years according to Bureau were more than $30 \%$ of the total population of developing countries as against $17 \%$ of developed countries. It reports that Ethiopia, Nigeria, Parkistan, both India and Mexico have $43 \%, 45 \%, 38 \%$ and $32 \%$ of their population under the age of 15 respectively. The youth dependency ratio to economically active ages (16-64 years) is relatively very high in countries with such age pattern and in this case, the support expected from the work-force in developing nations is almost double of the developed nations.

Federal Ministry of Health (2007) estimated that 1.8 million orphans are living with HIV/AIDS in 2003 while there was an increase of about 598,000 orphans in 2005. Consequently, the cost of health care services through the provision of antiretroviral increased (Ijaiya et al., 2007). On the other hand, HIV/AIDS are responsible for $7.7 \%$ of mortality world-wide in the children under five years old (Tindyebera et al., 2006) .In Nigeria, the Federal Ministry of Health (2007) revealed that Nigeria accounts for $14 \%$ of total African burden on HIV/AIDS in addition to $90 \%$ of infected children that takes place through vertical transmission - from mother to child, sexual contacts, exposure to blood and blood products. Population Reference Bureau (PRB) (2008) conducted statistical study in Nigeria and noted that infant mortality rate in 2007 was 100 per 1000 and life expectancy of 44 years. This according to the report is high when compared with Morocco, which showed mortality rate of about 44 per 1000 and 70 years life expectancy rate. The epidemic has reduced life expectancy by more than 20 years, slowed economic growth and population, moreover increased household poverty (UNAIDS, 2006). Its break-out all over the world showed that about 1.9 million people were newly infected in 2008 in Sub-Saharan Africa UNAIDS (2006). The Federal Ministry of Health (2005) (2007) estimated that about 5.4\% of Nigerians are living with HIV/AIDS with $3.6 \%$ prevalence rate and this portends danger for a country with a population figure of approximately 150 million people. Similarly, Akpan (2017) reports that the current estimated prevalent rate of HIV/AIDS in Nigeria is 3.4 million persons with Ebonyi state accounting for 260,000 persons with only 4000 persons on drugs in the state. Abasiubong, Udo, Idung and UmoiyohoS (2012) and Varga (2001) observed that sexual behaviour and attitude are the most common factors contributing to the upsurge of HIV/AIDS in developing countries especially Nigeria. Ijaiyaet al.(2007) posited that the greatest challenge of HIV/AIDS is not just the ill-health of the patients, but other factors such as the associated consequences on the population and economic sectors of the country. This phenomenon has created a gap in development arising from drastic fall in productivity of patients in particular and the country at large. It has also increased the cost of health care services, reduced savings and capital accumulation, reduced funding for other projects, increased orphanage homes with the attendant social ills since health care facilities represent a key point of contact with people living with HIV/AIDS, who are in need of prevention, treatment and support (Benson et al., 2011). Ogunbosi et al., (2011) submit that Provider Initiated Testing and Counselling (PITC) presents an opportunity to ensure that HIV/AIDS is systematically diagnosed in health facilities so as to unveil the status and facilitate access to needed HIV/AIDS support program.

It is against this background that this study intends to evaluate, from 2010 to 2014, the behavioural and socio-economic implications of HIV/AIDS patients on economic development of Ebonyi State, Nigeria with specific interest on estimating the behavioural pattern, socio-economic impact and challenges on population growth and economic development. From literatures, the spread of the virus is associated with many factors prominent among them are economic, social-cultural and epidemiological variables and that since economic factors revolve around labour migration, states like Ebonyi may risk meaningful economic growth. Ebonyi state which has an estimated population of 2,173,501 with land mass of $5,935 \mathrm{~km}^{2}$ and about $75 \%$ of the population dwelling in rural areas, can record significant strides in agricultural production if the spread of HIV/AIDS is effectively checked.

The only Federal Teaching Hospital (FETHA), situated in the state capital, Abakaliki with Communicable Control 
Disease and Research Unit (CCDRU) was selected as the study point. FETHA is strategically situated in the state capital as it provides health care services within and other neighbouring states of Enugu, Cross River and Benue. This study is expected to expose trends of HIV/AIDS syndrome in Ebonyi state while educating victims and non-victims on the minimum expected behaviour strategies that can prevent contracting the virus respectively.

This study is anchored on theories of Social Measures and Prevention Strategies. The theories emphasise on behavioural adjustments and appropriate application of preventive strategies for protection from HIV. Weinhardt, Carey, Johnson and Bickham (1999) highlighted the proven strategies to include sex education, needle exchange programmes, safe injection sites, safe sex, serosorting, sexual abstinence and immigration regulation submitting further that populations that access HIV testing are unlikely to practice high risk behaviours of contracting HIV. Weller and Davis (2002) adds that appropriate use of condom is a proven strategy that curtails the spread of HIV during sexual intercourse while Anglemyer, Rutherford, Horvath, Baggaley, Egger and Siegfrid (2013) contend that HIV is significantly less likely to be transmitted to uninfected partner where the positive partner is receiving treatment in the case of Treatment as Prevention (TasP) option.

\section{Empirical Framework}

A study conducted by networks of People Living with Hiv/AIDS (PLWHAs) and supported by International Labour Organisation (ILO) on four states in India revealed that the effect of income cuts is more on PLWHAs and their families. Amid increasing household expenditure, education of the children is compromised as $38 \%$ of the sampled study withdrew their children from schools, (ILO, 2006). Nandakumar, Schreider, Butera, Pitaayanom, Kongslin and Wattana $(2000,2002)$ showed that in Rwanda less than $30 \%$ of HIV positive patients were able to meet health care services from their own resources while some paid for their health care services by borrowing and selling of assets. Bharat (1997) discovered that AIDS drastically affected the economic wellbeing of the households in Mumbai with wives yet to be affected experiencing the burden of maintaining the house as their spouses lost jobs.

On education front, teachers succumb to AIDS preventing children from education, the orphans drop out of school for lack of parental support to seek alternative means of survival. UNAIDS reports that human capacity in agriculture which is the main stay of African economies encounter severe shortages as those affected are within their agricultural productive ages.

Greener (2002) reports that the increased mortality will result in a smaller skilled population and labour force who are predominantly youths with less knowledge and work experience metamorphosing into reduced productivity. Risley, Drake and Donald (2012) notes that AIDS has significant impacts on women and therefore those employing good numbers of women may be economically stifled.

Greener (2002) also adds that AIDS weakens the taxable population thereby reducing the resources available for government expenditure on other sectors of the economy. Over (1992) predicts that AIDS would slow economic growth in African countries due to decreasing life expectancies and the lowering of gross national product. Poverty is an overarching factor that increases vulnerability to, and the impact of, HIV. The poor segment may have little choice than to adopt risky behaviours including transactional and intergenerational sex, early marriage, and relationships that expose them to violence and abuse (UNAIDS 2017). The risk of trafficking and sexual exploitation is also higher for young women and adolescent girls, especially those living in poverty (UNAIDS 2015).

On measures to check the scourge of the epidemic, Beletsky, Thomas, Smelyanskaya, Artamova, Shumskaya, Dooronbekova, Mukambetov, Doyle and Tolson (2012) advise targeting the vulnerable with strategies that aligns to the activities of law enforcement personnel, public health policies and practices and such can be done through improved policy, training and proper coordination.

A lack of youth-friendly HIV treatment, support and care services prevent many infected patients from accessing ART. Studies from Southern Africa conducted by Lamb (2014) and Bygrave (2012) indicate how loss of yearly follow up after enrolling on ART is higher among young people compared to both adults and children.

Ainsworth and Over (1994), World Bank (1995, 1997), Robalino, Jenkins and El-Marufi (2002) agree that the effect of HIV/AIDS are linked with the increase in morbidity and mortality rates of the sexually active people. The implications include decline in productive labour force due to the associated sickness and worry of being HIV positive, rise in health care spending and reduction in capital accumulation (savings). Reduction in savings and capital accumulation directly affect investments on human development (education at different levels), reduction in physical structures and other areas that can propel national development and contribute to Gross Domestic Product (GDP). 
Rim (1973) and Albarracin, Gillette, Earl, Glasman, Durantini and Ho (2005) agree that persuasive campaigns from health authorities designed to prevent spread of HIV/AIDS is a simple preventive strategy because of the attendant increased knowledge about the virus. Similarly, Crosby and Bounse (2012) submit that consistent use of condom reduces by about $80 \%$, the risk of heterosexual HIV transmission while Baptista and Ramalho-Santos (2009) agree that the use of spermicide nonoxynol-9 may increase the risk of transmission due to increase in virginal and rectal irritation. Celum and Baeten (2012) point out that infection rates may reduce by $40 \%$ among African women if a vaginal gel laced with tenofovir is used soon after sex. Seigfried, Muller, Deeks and Volmink (2009) note that circumcision reduces the risk of HIV infection in Sub-Saharan Africa by $38 \%$ in heterosexual men and on the basis of the finding, WHO and UNAIDS (2007) approved male circumcision as a means of reducing female-to-male HIV transmission.

Weinhardt, Carey, Johnson and Bickham (1999) and National Institute of Allergy and Infectious Diseases (NIAID) (2011) note that administration of antiretrovirals to HIV patients early protected $96 \%$ of partners from being infected. Similarly, in a study conducted by the American Centres for Disease Control and Prevention (CDC) in partnership with the Thailand Ministry of Public Health indicated that about $48.9 \%$ reduced incidence of the virus among the groups of subjects that received antiretroviral drug tenofovir. Prescribe International (2012) summarise that the use of a single agent zidovudine reduces the risk of further infection after exposure while on follow-up strategy, Desai, Woodhall, Nardone, Burns, Mercey and Gilson (2015) agree that treatment facilities encourage return of the previously treated ones to establish that the infection is properly managed by retesting the patients.

Kurth, Celum, Baeten, Vermund and Wasserheit (2011) and Coutsoudis, Kwaan and Thomson (2010) observe that a combination of anti-viral while pregnant and after delivery in addition to bottle feeding rather than breast milk reduces mother to child transmission of the virus; but that if exclusive breast feeding cannot be avoided, an extension of administration of antiretroviral prophylaxis to the child reduces the chances of transmission.

On vaccination, UNAIDS (2012) reports that no known effective vaccine for HIV/AIDS has been reported while Reynell and Trkola (2012) submit that vaccine RV144 has partial efficacy rate of about 30\% indicating high chances that an effective vaccine may be developed soon.

\section{Methodology}

Survey research approach was adopted and information was generated from primary sources. The information was subjected to rigorous content and validity analysis to establish their consistency and reliability. Survey system enables collection of detailed factual information and equally describes existing phenomena (Bowling, 1999). The population for the study consisted of two hundred and fifty (250) patients drawn from the hospital's records of the patients that reported for counselling and access Antiretroviral Drugs. Simple random sampling technique was used while pre-determined questionnaire consisting of ten statements on the implication of HIV/AIDS on population and economic growth was applied. The centre/unit designated for counselling and distribution of antiretroviral drugs to HIV/AIDS patients in the hospital is called Communicable Control Disease and Research Unit (CCDRU). Questionnaires were distributed through a Research Assistant and data analysis was based on the retrieved duly completed copies of the two hundred and ten (210) questionnaires. This is $84 \%$ and $16 \%$ response and non-response rates respectively. Descriptive statistics like percentile was used in determining the implications of HIV/AIDS on socio-demographic characteristics of respondents and other specific objectives of the study.

\section{Results}

\subsection{Demographic Characterisation}

The result showed that about 2583 HIV/AIDS cases were officially and clinically reported at the Federal Teaching Hospital, Abakaliki (Table 1). On the other hand, $62 \%$ of HIV/AIDS patients in Ebonyi state are females while $38 \%$ are males. The educational degree level of the cases were $76 \%$ tertiary while secondary is about $14.3 \%$ and only $9.5 \%$ had primary education. Age group were separated into four categories as shown in the Table $2.71 .9 \%$, $16.2 \%$ and $11.9 \%$ were the ages of those between 26 to 64 years, above 65 years and below 25 years respectively that contracted the virus. The marital status catigorization of the patients were married, single, widowed and divorced with about $11.4 \%, 46.2 \%, 30 \%$ and $12.4 \%$ are respectively. The survey indicated the patients' occupation and the results found that the patients distributed among 50\% unemployed/students, $28.6 \%$ trading/self-employed while $21.4 \%$ civil servant (Table 2 ). 
Table 1. Number of HIV/AIDS reported cases from 1st January, 2010 to 31st December, 2014, in Ebonyi state

\begin{tabular}{llllllr}
\hline Gender/year & $\mathbf{2 0 1 0}$ & $\mathbf{2 0 1 1}$ & $\mathbf{2 0 1 2}$ & $\mathbf{2 0 1 3}$ & $\mathbf{2 0 1 4}$ & Total \\
\hline Male & 150 & 138 & 307 & 188 & 133 & 916 \\
Female & 256 & 252 & 558 & 372 & 229 & 1667 \\
Total & 406 & 390 & 865 & 560 & 362 & 2583 \\
\hline
\end{tabular}

Source: Field survey, 2019.

Table 2. Frequency of demographic characteristics of HIV/AIDS Patients in Ebonyi state

\begin{tabular}{|c|c|c|c|}
\hline & Demographic characteristics & Frequency & Percentage \\
\hline \multirow{4}{*}{1} & Gender & & \\
\hline & Male & 80 & 38.1 \\
\hline & Female & 130 & 61.9 \\
\hline & Total & 210 & 100 \\
\hline \multirow{5}{*}{2} & Educational level & & \\
\hline & Tertiary Institution & 160 & 76.2 \\
\hline & Secondary School & 30 & 14.3 \\
\hline & Primary School & 20 & 9.5 \\
\hline & Total & 210 & 100 \\
\hline \multirow{6}{*}{3} & Age & & \\
\hline & Below 25 & 25 & 11.9 \\
\hline & $26-45$ & 70 & 33.3 \\
\hline & $46-64$ & 81 & 38.6 \\
\hline & 65 and above & 34 & 16.2 \\
\hline & Total & 210 & 100 \\
\hline \multirow{6}{*}{4} & Marital Status & & \\
\hline & Married & 24 & 11.4 \\
\hline & Single & 97 & 46.2 \\
\hline & Widowed & 63 & 30.0 \\
\hline & Divorced & 26 & 12.4 \\
\hline & Total & 210 & 100 \\
\hline \multirow{5}{*}{5} & Occupation & & \\
\hline & Trading/self employed & 60 & 28.6 \\
\hline & Civil servant & 45 & 21.4 \\
\hline & Unemployed/students & 105 & 50.0 \\
\hline & Total & 210 & 100 \\
\hline
\end{tabular}

Source: Field survey, 2019.

Table 3 evolves the way the virus was acquired and the result showed that $56.7 \%$ contracted the disease through sexual intercourse, $14.7 \%$ through blood transfusion, $12.4 \%$ through unsterilized sharp objects, $11.4 \%$ through mother to child and $4.8 \%$ from barbing saloon. Moreover, the table showed that the patients, about $73.4 \%$ have contracted the virus for 4 years, $21 \%$ between 5 to 8 years and $5.7 \%$ above 9 years. On how it was detected, $64.8 \%$ knew their status when they took ill and was tested, $31 \%$ through routine health checks and $4.2 \%$ when they wanted to donate blood. 
On their sex behaviour since they became positive, $71.4 \%$ of the patients have had unprotected sex since they contracted it while $28.6 \%$ have not. On checking the spread, $62.9 \%$ averred to distribute the virus indiscriminately, $22.4 \%$ are indifferent, $10 \%$ and $4.7 \%$ have stopped having sex and organise talks for the youths on the challenges of HIV/AIDS respectively.

Table 3. Determination of how the virus was contracted and other related issues

\begin{tabular}{|c|c|c|c|c|}
\hline $\mathbf{S} / \mathbf{n}$ & Items & Responses & Frequency & Percentage \\
\hline \multirow{5}{*}{1} & \multirow{5}{*}{ How did you contact the virus? } & Sexual intercourse & 119 & 56.7 \\
\hline & & Blood Transfusion & 31 & 14.7 \\
\hline & & Sharing of unsterilized sharp objects & 26 & 12.4 \\
\hline & & $\begin{array}{l}\text { Mother to child during pregnancy/breast } \\
\text { feeding }\end{array}$ & 24 & 11.4 \\
\hline & & Barbing saloon & 10 & 04.8 \\
\hline \multirow{3}{*}{2} & \multirow{3}{*}{$\begin{array}{l}\text { For how long have you been } \\
\text { living with the virus? }\end{array}$} & $1-4$ years & 154 & 73.3 \\
\hline & & $5-8$ years & 44 & 21.0 \\
\hline & & More than 9 years & 12 & 05.7 \\
\hline \multirow{3}{*}{3} & \multirow{3}{*}{ How was the virus discovered? } & Routine check-up & 65 & 31 \\
\hline & & When I took ill & 136 & 64.8 \\
\hline & & When I wanted to donate blood & 09 & 04.2 \\
\hline \multirow[b]{2}{*}{4} & \multirow{2}{*}{$\begin{array}{l}\text { Have you had any unprotected } \\
\text { sexual intercourse since } \\
\text { infected? }\end{array}$} & Yes & 150 & 71.4 \\
\hline & & No & 60 & 28.6 \\
\hline \multirow{4}{*}{5} & \multirow{4}{*}{$\begin{array}{l}\text { What effort are you making to } \\
\text { check the spread of the virus? }\end{array}$} & No effort & 47 & 22.4 \\
\hline & & $\begin{array}{l}\text { Somebody gave me, I must give to as many } \\
\text { as possible before I die }\end{array}$ & 132 & 62.9 \\
\hline & & I have stopped having sex & 21 & 10.0 \\
\hline & & I organise talks for the youths on AIDS & 10 & 04.7 \\
\hline
\end{tabular}

Source: Field survey, 2019.

The results on Table 4 showed that $80.5 \%$ of the patients affirmed that the virus negatively affects their productivity. Reacting further, $54.8 \%$ of the patients vowed not to be productive because of the fear of death.

On the administration of antiretroviral drugs, $19.5 \%, 14.3 \%$ and $11.4 \%$ assumed that they are negatively influenced because the antiretroviral drug is non-curative, feeling of irritation of everything around them and pre-occupied ruminating on how they contracted the virus.

Reacting on the trend of HIV/AIDS patients, $84.3 \%$ agreed that it is increasing while $15.7 \%$ disagreed. $45.2 \%$ of the patients attributed the increase to the behavioural attitudes of the patients while $31 \%$ and $23.8 \%$ blamed poor government policies and rising cases of prostitution occasioned by hardship respectively. 
Table 4. Determination of the socio-economic impact of HIV/AIDS on economic development of Ebonyi state

\begin{tabular}{|c|c|c|c|c|}
\hline $\mathbf{S} / \mathbf{n}$ & Items & Responses & Frequency & Percentage \\
\hline \multirow{2}{*}{1} & \multirow{2}{*}{$\begin{array}{l}\text { Is your productivity negatively affected by this } \\
\text { health challenge? }\end{array}$} & Yes & 169 & 80.5 \\
\hline & & No & 41 & 19.5 \\
\hline \multirow{4}{*}{2} & \multirow{4}{*}{$\begin{array}{l}\text { If your answer to " } 1 \text { " above is yes, why are you } \\
\text { negatively affected when antiretroviral drug is } \\
\text { there to support you }\end{array}$} & The drug is not curative & 41 & 19.5 \\
\hline & & $\begin{array}{l}\text { Why working when I will eventually } \\
\text { die of the sickness }\end{array}$ & 115 & 54.8 \\
\hline & & I hate everything around me & 30 & 14.3 \\
\hline & & $\begin{array}{l}\text { I am preoccupied thinking of how I } \\
\text { got it rather than working/being } \\
\text { productive }\end{array}$ & 24 & 11.4 \\
\hline \multirow{2}{*}{3} & \multirow{2}{*}{$\begin{array}{l}\text { Do you feel HIV/AIDS patients are increasing } \\
\text { since you started coming for counselling and } \\
\text { treatment? }\end{array}$} & Yes & 177 & 84.3 \\
\hline & & No & 33 & 15.7 \\
\hline \multirow{3}{*}{4} & \multirow{3}{*}{$\begin{array}{l}\text { What is responsible for the increase if your } \\
\text { response to question ' } 3 \text { ' is yes? }\end{array}$} & Poor Govt policy & 65 & 31 \\
\hline & & Behavioural attitudes of the patients & 95 & 45.2 \\
\hline & & Availability of prostitute & 50 & 23.8 \\
\hline \multirow{5}{*}{5} & \multirow{5}{*}{$\begin{array}{l}\text { What measures do you think can be put in place } \\
\text { to check the increase of HIV/AIDS patients }\end{array}$} & $\begin{array}{l}\text { Enforceable law against indecent } \\
\text { dressing }\end{array}$ & 54 & 25.7 \\
\hline & & $\begin{array}{l}\text { Control on the usage of social } \\
\text { network on our phones }\end{array}$ & 62 & 29.5 \\
\hline & & Ban of prostitution & 50 & 23.8 \\
\hline & & Free distribution of condoms & 14 & 06.7 \\
\hline & & Engaging the youths/creation of jobs & 30 & 14.1 \\
\hline
\end{tabular}

Source: Field survey, 2019.

\section{Discussion}

Gender analysis of HIV/AIDS patients in Ebonyi state within the period under review as contained on Table 1 indicates that $1667(64.5 \%)$ and 916 (34.5\%) were women and men respectively. This is consistent with the finding of UNAIDS (2015) which implied that women accounts for more than half of the people living with the virus, disproportionately affecting women in many countries. This trend challenges the economicat growth in many aspects including reduced population, reduced skilled and non-skilled hands, increased poverty as sectors employing women will be economically affected. The long-run effect of this is a drop in population and more dependants/orphans. This is equally in tandem with the findings of the Population Reference Bureau (2008) that 45\% of Nigeria's population are under the ages of 15 and this challenges economic development due to pressure on the working age to support the dependants.

On educational level, responses obtained showed that $76.2 \%$ of the sampled patients were graduates of tertiary institutions. This disclosure predicts slow in economic growth as most organisations may disengage them thereby weakening the taxable population as noted by Greener (2002). The ages mostly affected are between 26-64 years old. This accounts for $71.9 \%$ of the victims and they are the productive ages of most economies. This aligns with the submission of Over (1992) who noted that AIDS reduces life expectancy, gross domestic product (GDP) and human capacity particularly in agricultural sector where Ebonyi state is notably prominent.

Sampled victims in the categories of single and widowed accounted for $76.2 \%$ and it may be associated with their vulnerability and the struggle to sustain the family after the loss of their spouses. This finding agrees with Bharat (1997) who noted that AIDS affected economic wellbeing of households in Mumbai with partners (wives unaffected bearing the burden of sustaining the family).

Traders/self-employed and unemployed/students are $78.6 \%$ of the victims sampled in the state. Poverty is an over-bearing factor that increases vulnerability. This category has little choice than to adopt risky behaviours of 
contracting the virus such as engaging in uncertified medical treatment early marriages and indiscriminate sexual behaviours (UNAIDS 2017).

Moreover, the way the virus was contracted was investigated and about $71.4 \%$ contracted through sexual intercourse and blood transfusion. This finding agreed with poverty factor as noted by UNAIDS (2017). The less informed indulge in unwholesome sexual practices to survive. They engage in trafficking of sexual exploits due to poverty (UNAIDS, 2015).

The results indicated that $94.3 \%$ contracted the disease for between (1-8) years but when a single agent zidovudine is applied it reduces the risk of subsequent infection. This agreed with the assertion of Lamb (2014) and Bygrave (2012) that loss of follow-up after enrolling on ART is high among young people due to the stigma associated with early disclosure of status.

Routine check at ill health and unprotected sexual contact accounted for $95.8 \%$ and $71.4 \%$ respectively. This affirms the study of Crossby and Bounse (2012) that constant and appropriate use of condom reduces heterosexual transmission by about $80 \%$ over a long time.

On the productivity of the patients, $80.5 \%$ of the sampled patients admitted poor productivity occasioned by persistent and re-occurring failing health while $54.8 \%$ preferred remaining idle due to the stigma attached to the disease. This reduces economic growth and it agrees with the position of Greener (2012) who submits that increased mortality results in smaller labour force and slows down the rate of economic development. The socio-economic implications of this are increase in poverty, increase in inequality and slow/poor economic growth rate. This finding also supports the views of Sharp, Bailes, Chaudhuri, Rodenburg, Santiago and Hahn (2001) who noted that economic development must be seen in terms of poverty, unemployment and inequality reduction.

On the position of the epidemic, $84.3 \%$ admitted that HIV/AIDS patients are increasing while $76.2 \%$ attributed the increase to poor government policies and behavioural tendencies of the patients. This supports the positions of Weinhardtet al. (1999), Rim (1973) and Albarracinet al. (2005) that populations who access HIV testing are less likely to engage in risky and behaviours capable of contracting the virus and that persuasive campaigns through advertisement educates people on the inherent health challenges of HIV/AIDS and the prevention options.

$79 \%$ of the patients advocated for legal options to control the rising cases of HIV/AIDS and that such laws should target illicit trades such as prostitution and youth engagement in social network. This option is in agreement with the submissions of Beletskyet al. (2012) who recommended that efforts targeting vulnerable groups should engage proper alignment between law enforcement personnel and public health policies and practices explaining further that synergy can be obtained through policy statement, training and coordination. Prostitution involves indiscriminate sex for economic considerations and stigmatisation forces the illicit trade to attract cross border/state/city/town migration. This aligns with the findings of Bonnel (2000) that the spread of HIV/AIDS is connected with economic factor aimed at poverty reduction.

The socio-economic implications of these are increase in poverty, inequality and slow/poor economic growth rate. This finding supports the findings of Sears (1996) who noted that economic development must be seen in terms of poverty, unemployment and inequality reduction. From their reactions, 177(84.3\%) agreed that since they started accessing counselling and treatment, the number of infected persons have continued to increase, suggesting irresponsible behaviours of youths as possible indicators.

\subsection{Recommendations}

Based on the findings of this study, the following recommendations are made:

- Sensitization of HIV/AIDS patients on the need for positive behavioural/attitudinal change to save the productive age.

- Government should regularly organize educative programs on how increased mortality resulting from scourge of HIV/AIDS means smaller labour force and it slows down the rate of economic development.

- Introduction of supportive measures by the government to reduce mother-to-child transmission of HIV/AIDS. This is expected to strengthen the taxable population thereby increasing the resources available for government on other sectors of the economy. Concerted efforts are required to ensure that even those affected can procreate to their desired number of children to sustain population growth and development since a greater percentage of those patients are women.

\section{Conclusion}

This study examined various factors responsible for HIV/AIDS infection in the Ebonyi state and noted a steady 
increase of HIV/AIDS infected persons. This trend portends danger for population growth and economic development if behavioural attitude of the patients is not altered. The socio-economic impact of HIV/AIDS was considerably grave showing evidence that women are more vulnerable to HIV/AIDS infection. This calls for educative programs on HIV/AIDS related stigma and discrimination. Positive behavioural change that supports use of condom, abstinence and adherence to one sex partner become imperative since there is a strong association between unprotected sexual intercourse and HIV/AIDS infection.

\section{Competing Interests Statement}

The authors declare that there are no competing or potential conflicts of interest.

\section{References}

Abasiubon, F., Udoh, B. S., Idung, A. U., \& Umoiyoho, A. J. (2012). Attitudes and sexualbehaviours of unmarried people with HIV/AIDS living in the Niger Delta region ofNigeria. Journal of Mental Health in Family Medicine.

AIDS/World Health Organisation UNAIDS: Report on the Global AIDS Epidemic. UNAIDS: Geneva, 2006

Ainsworth M. and Over. (1994). AIDS and African Development.World Bank Research Observer, 9, No. 2.https://doi.org/10.1093/wbro/9.2.203

Akpan, N. (2017). What is the latest HIV/AIDS prevalence rate in Nigeria and Ebonyistate.HIV Cases in Ebonyi hit 260,000/The Guardian Nigeria News-Nigeria and World NewsNigeria-The Guardian Nigeria News-Nigeria and World News. Retrieved on 17th January, 2020 from www.guardian.ng/news/hivaids-cases-in-ebonyi-hit-2260,000/.

Alaofin, O. S., Naidoo, K., \& Sibanda, W. (2020). Socio-Economic Determinants of HIV-Malaria Co-Infection among Adults in the North Central Zone, Nigeria. Global Journal of Health Science, 12(1). https://doi.org/10.5539/gjhs.v12n1p9

Albarracin D., Gillette J. C., Earl, A. N., Glasman, L. R., Durantini, M. R., \& Ho, M. H. (2005). Atest of major assumptions about behaviour change: a comprehensive look at the effects of passive and active HIV-prevention interventions since the beginning of the epidemic. Psychological Bulletin, 131(6). https://doi.org/10.1037/0033-2909.131.6.856

Anglemyer, A., Rutherford, G. W., Horvath, T., Baggaley, R. C., Egger, M., \& Siegfried, N. (2013).Antiretroviral therapy for prevention of HIV transmission in HIV-discordantcouples. https://doi.org/10.1002/14651858.CD009153.pub3

Bailes, E., Chaudhuri, R. R., Santiago, M. L., Bibollet, R. E., Hahn, B. H.,\& Sharp, P. M. (2002). The Evolution of Primate Lentivirus and the origin of AIDS.In the Molecular epidemiology of human virus. Kluwer Academic Publishers. https://doi.org/10.1007/978-1-4615-1157-1_5

Baptista, M., \& Ramalho-Santos, J. (2009). Spermicides, microbicides and antiviral agents: recent advances in the development of novel multi-functional compounds. Mini reviews in medicinal chemistry, 9(13), 1556-1567. https://doi.org/10.2174/138955709790361548

Beletsky, L., Thomas, R., Smelyanskaya, M., Artamonova, I., Shumskaya, N., Dooronbekova, A., ... \& Tolson, R. (2012). Policy reform to shift the health and human rights environment for vulnerable groups: the case of Kyrgyzstan's instruction 417. Health Hum Rights, 14(2), 34-48.

Benson, O. N., Lauretta, M. O., Onyinye, U. A., Onuorah, O. C., Gideon, I., \& Chioma, I. (2013). Provider initiated Human Immunodeficiency Virus testing and counseling in children, our experience at the Federal Teaching Hospital Abakaliki, South Eastern Nigeria. African Journal of Medical and Health Sciences, 12(2), 96. https://doi.org/10.4103/2384-5589.134904

Bharat, S. (1997). Facing the challenge household and community response to HIV/AIDS in Mumbai, India (Executive Summary).HIV/AIDS Research in India. New Delhi: National AIDS Control Organization, Ministry of Health and Family Welfare, 372-5.

Bonnel, R. (2000). Economic Analysis of HIV/AIDS. Geneva, UNAIDS.

Bowling, A. (1999). Research methods in Health: Investigating Health Services. Buckingham: University Press.

Bygrave, H., Mtangirwa, J., Ncube, K., Ford, N., Kranzer, K., \& Munyaradzi, D. (2012). Antiretroviral therapy outcomes among adolescents and youth in rural Zimbabwe. PloS one, 7(12). https://doi.org/10.1371/journal.pone.0052856 
Carroll, R. (2003). Swaziland has world's highest Aids rate. The Guardian, London: GMG. ISSN 0261 - 3077. Retrieved from https://en.wikipedia.org/wiki/prevention_of_HIV/AIDS

Celum, C., \& Baeten, J. M. (2012). Tenofovir-based pre-exposure prophylaxis for HIV prevention: evolving evidence. Current Opinion in Infectious Diseases. https://doi.org/10.1097/QCO.0b013e32834ef5ef

Conjoh, A. M., Zhou, Z., \& Xiong, J. (2011). Socio-cultural factors affecting the spread of HIV/AIDS among adolescents in Sierra Leone. The Social Sciences, 6(4), 269-276. https://doi.org/10.3923/sscience.2011.269.276

Coutsoudis, A., Kwaan, L., \& Thomson, M. (2010). Prevention of vertical transmission of HIV-1 in resource-limited settings. Expert review of anti-infective therapy, 8(10), 1163-1175. https://doi.org/10.1586/eri.10.94

Crosby, R., \& Bounse, S. (2012). Condom effectiveness: where are we now?. Sexual health, 9(1), 10-17. https://doi.org/10.1071/SH11036

Desai, M., Woodhall, S. C., Nardone, A., Burns, F., Mercey, D., \& Gilson, R. (2015). Active recall to increase HIV and STI testing: a systematic review. Sex Transm Infect, 91(5), 314-323. https://doi.org/10.1136/sextrans-2014-051930

Eaton, L. A., \& Kalichman, S. C. (2009). Changes in transmission risk behaviors across stages of HIV disease among people living with HIV. Journal of the Association of Nurses in AIDS Care, 20(1), 39-49. https://doi.org/10.1016/j.jana.2008.10.005

Egerton, F. C. C. (1939). African Majesty: A Record of Refuge at the Court of the King of Bangangte in the French Cameroons. New York: C. Scribner's Sons.

Federal Ministry of Health HIV/Sero - Prevalence Sentinel Survey: National AIDS/STDs Control Programme, Federal Ministry of Health, Abuja, Nigeria, 2005.

Greener, R. (2002). AIDS and macroeconomic impact. State of the art: AIDS and economics. IAEN, 49-55.

Heiman, H. J., \& Artiga, S. (2015). Beyond health care: the role of social determinants in promoting health and health equity. Health, 20(10), 1-10.

Hirsch, V. M., Olmsted, R. A., Murphey-Corb, M., Purcell, R. H., \& Johnson, P. R. (1989). An African primate lentivirus (SIV sm closely related to HIV-2. Nature, 339(6223), 389-392. https://doi.org/10.1038/339389a0

HIV exposure through contact with body fluids. (2012). Prescrire International, 21(126). Retrieved from https://en.wikipedia.org/wiki/prevention_of_HIV/AIDS

Ijaiya, G. T., Usman, A., Ijaiya, M. A., \& Alabi, L. A. (2007). Causes and socio-economicconsequences of HIV/AIDS in Kwara state. Nigerian Journal of Legislative Affairs, 3(1\&2): A publication of Policy Analysis and Research Project (PARP), National Assembly ofNigeria, Maitama, Abuja.

ILO project - Assigning the socio-economic impact of HIV/AIDS on PLWAHS and their families in India -undertaken. $\quad$ Retrieved 14th November, fromhttps://www.ncbi.nlm.nih.gov/pmc/articles/PMC3329095/

Indecent Dressing: Osun state. Retrieved from http://www.osun state.com.

Ivan Pavlov (1927). Ivan Pavlov Classical Conditioning.Theory, Experiments and Contributions to Psychology. $\begin{array}{lllll}\text { Retrieved on } & \text { 1st } & \text { February, } & 2020 & \text { from }\end{array}$ https://study.com/academy/lesson/ivan-pavlov-and-classical-conditioning-theory-experiments-contributions -to-psychology.html

Kalichman, S. C., Cain, D., \& Simbayi, L. C. (2010). Behavioral changes associated with testing HIV-positive among sexually transmitted infection clinic patients in Cape Town, South Africa. American journal of public health, 100(4), 714-719. https://doi.org/10.2105/AJPH.2009.162602

Kayita, J., Musoke, P., Eley, B., Nduati, R., Coovadia, H., Bobart, R., ... \& Kieffer, P. M. (2004). Handbook on paediatric AIDS in Africa. D. Tindyebwa (Ed.). Kampala: African Network for The Care of Children Affected by AIDS.

Kinicki, A., \& Kreitner, R. (2003). Organisationalbehaviour: key concepts, skills and best practices. McGraw Hill, Irwin.

Kurth, A. E., Celum, C., Baeten, J. M., Vermund, S. H., \& Wasserheit, J. N. (2011). Combination HIV prevention. 
Retrieved from https://en.wikipedia.org/wiki/prevention_of_HIV/AIDS

Lamb, M. R., Fayorsey, R., Nuwagaba-Biribonwoha, H., Viola, V., Mutabazi, V., Alwar, T., ... \& Elul, B. (2014). High attrition before and after ART initiation among youth (15-24 years of age) enrolled in HIV care. AIDS (London, England), 28(4), 559. https://doi.org/10.1097/QAD.0000000000000054

Lamptey, P., Wigley, M., Carr, D., \& Collymore, Y. (2002). Facing the HIV/AIDS pandemic. Population Reference Bureau.

Loth, R. (1988). AIDS Protests close FDA Headquarters. Boston Globe. Retrieved from https://en.wikipedia.org/wiki/prevention_of_HIV/AIDS

Luthans, F. (1985). OrganisationalBehaviour. McGraw Hill Series, (Tien Press PteLte) Singapore.

Merson, M. H., O'Malley, J., Serwadda, D., \& Apisuk, C. (2008). The history and challenge of HIV prevention. Lancet, 372. https://doi.org/10.1016/S0140-6736(08)60884-3

Nandakumar, A. K., Schneider, P., Butera, D., Pitaayanom, S., Kongslin, S., \& Wattana, S. (2000, July). Use and expenditures on outpatient health care by a sample of HIV-positive individuals in Rwanda. In International AIDS Economic Network (IAEN) Symposium on the Economics of AIDS, Durban, South Africa, July (Vol. 7, pp. 53-101).

Nandakumar, A. K., Schreider, P., Butera, D., Pitaayanom, S., Kongslin, S., \& Wattana, S. (2000). Use and expenditures on out-patient health care by a sample of HIV positive individuals in Rwanda. A paper presented at the International AIDS Economic Network (IAEN) Symposium on the economics of AIDS, Durban, South Africa. Retrieved from Population Bulletin, 2002

National Guideline for Paediatric HIV/AIDS. (2007). Treatment and Care; i Federal Ministry of Health, Nigeria, Abuja, 2007.

National Institute of Allergy and Infectious Diseases. (2011). Treating HIV-infected people with antiretrovirals protects partners from infection.

Ogunbosi, B. O., Oladokun, R. E., Brown, B. J., \& Osinusi, K. I. (2011). Prevalence and clinical pattern of paediatric HIV infection at the University College Hospital, Ibadan, Nigeria: a prospective cross-sectional study. Italian Journal of Pediatrics, 37(1), 29. https://doi.org/10.1186/1824-7288-37-29

Over, A. M., \& Health World Bank.Africa Technical Dept. Population (and Nutrition Division). (1992). The macroeconomic impact of AIDS in Sub-Saharan Africa. World Bank, Africa Technical Department, Population, Health and Nutrition Division.

Pepin, J. (2011). The Origin of AIDS (P. 311). Cambridge University Press. https://doi.org/10.1017/CBO9781139005234

Reynell, L., \& Trkola, A. (2012). HIV vaccines: an attainable goal?. Swiss medical weekly, 142, online.

Rimm, D. C. (1973). Thought stopping and covert assertion in the treatment of phobias. Journal of Consulting and Clinical Psychology, 41(3), 466-467. https://doi.org/10.1037/h0035379

Risley, C. L., Drake, L. J., \& Bundy, D. A. (2012).Economic impact of HIV and antiretroviral therapy on education supply in high prevalence regions. PloS one, 7(11).https://doi.org/10.1371/journal.pone.0042909

Robalino, D. A., Jenkins, C., \& Maroufi, E. K. (2002). The risks and macroeconomic impact of HIV/AIDS in the Middle East and North Africa: Why waiting to intervene can be costly. The World Bank. https://doi.org/10.1596/1813-9450-2874

Sharp, P. M., Bailes, E., Chaudhuri, R. R., Rodenburg, C.M., Santiago, M. O., \& Hahn, B. A. (2001). The origins of AIDS Viruses: where and when? Phil. Trans. R. Soc. London,B356.https://doi.org/10.1098/rstb.2001.0863

Sharp, P. M., Shaw, G. M., \& Hahn, B. H. (2005). Simian immunodeficiency virus infection of chimpanzees. Journal of virology, 79(7), 3891-3902. https://doi.org/10.1128/JVI.79.7.3891-3902.2005

Siegfried, N., Muller, M., Deeks, J. J., \& Volmink, J. (2009). Male circumcision for prevention of heterosexual acquisition of HIV in men. Cochrane database of systematic reviews, (2). https://en.wikipedia.org/wiki/prevention_of_HIV/AIDS.

Todaro, M. P., \& Smith, S. C. (2011).Economic Development. Peason Education Ltd,Edinburgh Gate, Harlow Essex CM202JE, England.

UNAIDS. (2012). The quest for an HIV vaccine. Retrieved from 
https://en.wikipedia.org/wiki/prevention_of_HIV/AIDS

UNAIDS. (2015). Empowering young women and adolescent girls Fast Track the End of the AIDS epidemic in Africa. Retrieved from https://en.wikipedia.org/wiki/prevention_of_HIV/AIDS

UNAIDS. (2017). When women lead, change happens.Retrieved from https://en.wikipedia.org/wiki/prevention_of_HIV/AIDS

UNAIDS. (2019). Women and HIV: A Spotlight on adolescent and Young Women.

UNAIDS/WHO Guidance of Provider Initiated HIV Testing and Counselling in Health facilities, Geneva: Joint United Nations Programme on HIV/AIDS (UNAIDS) and World Health Organisation (WHO), 2007.

Varga, C. A. (2001). The forgotten fifty percent: A review of sexual and reproductive healthresearch and programmesfocussed on boys and young men in sub-Saharan Africa. African Journal of Reproductive Health, 5, 175-95. https://doi.org/10.2307/3583334

Vidal, N., Peeters, M., Mulanga-Kabeya, C., Nzilambi, N., Robertson, D., Ilunga, W., ... \& Delaporte, E. (2000). Unprecedented degree of human immunodeficiency virus type 1 (HIV-1) group M genetic diversity in the Democratic Republic of Congo suggests that the HIV-1 pandemic originated in Central Africa. Journal of virology, 74(22), 10498-10507. https://doi.org/10.1128/JVI.74.22.10498-10507.2000

Wanyenze, R. K., Nawavvu, C., Ouma, J., Namale, A., Colebunders, R., \& Kamya, M. R. (2010). Provider-initiated HIV testing for paediatric inpatients and their caretakers is feasible and acceptable. Tropical Medicine \& International Health, 15(1), 113-119. https://doi.org/10.1111/j.1365-3156.2009.02417.x

Weinhardt, L. S., Carey, M. P., Johnson, B. T., \& Bickham, N. L. (1999). Effects of HIV counseling and testing on sexual risk behavior: a meta-analytic review of published research, 1985-1997. American journal of public health, 89(9), 1397-1405.

Weller, S. C., \& Davis-Beaty, K. (2002). Condom effectiveness in reducing heterosexual HIV transmission. Cochrane database of systematic reviews, (1). https://doi.org/10.1002/14651858.CD003255

World Bank. (1995). AIDS and Development moving beyond the partial paradigms. The World Bank Washington D.C.

World Bank. (1997).Confronting AIDS: Public Priorities in a Global Epidemic. New York, Oxford University Press.

\section{Copyrights}

Copyright for this article is retained by the author(s), with first publication rights granted to the journal.

This is an open-access article distributed under the terms and conditions of the Creative Commons Attribution license (http://creativecommons.org/licenses/by/4.0/). 